\title{
The complement system in Type 1 (insulin-dependent) diabetes
}

\author{
J.A. Charlesworth ${ }^{1}$, V.Timmermans ${ }^{1}$, J. Golding ${ }^{1}$, L. V.Campbell ${ }^{2}$, P. W. Peake ${ }^{1}$, B. A. Pussell ${ }^{1}$, D. Wakefield ${ }^{1}$ \\ and N. Howard ${ }^{1}$ \\ ${ }^{1}$ Department of Medicine, Prince Henry Hospital and ${ }^{2}$ Diabetes Centre, St. Vincent's Hospital, Sydney, Australia
}

\begin{abstract}
Summary. The complement proteins C1q, r, s, C2, C4, C3, factor $\mathrm{B}, \mathrm{C} 5, \mathrm{C} 6$, and the inhibitors, $\mathrm{C} 1$ inhibitor, factors I and $\mathrm{H}$ were measured in 35 patients with recently diagnosed Type 1 (insulin-dependent) diabetes, 76 patients with longerduration disease (30 with complications) and 43 first-degree healthy relatives. We found that $\mathrm{C} 1 \mathrm{q}, \mathrm{C} 4$ and $\mathrm{C} 3$ were reduced significantly in all groups of patients $(p<0.001$ for each protein in recent onset and uncomplicated patients; $p<0.01, p<0.01$ and $p<0.05$ respectively, for patients with complications) compared to 60 control subjects and that $\mathrm{C} 4$ was also reduced in healthy relatives $(p<0.001)$. C4 allotypes were examined in 63 subjects (selected from the patient groups) in order to clarify the role of null alleles in the production of the $\mathrm{C} 4$ abnormality. These showed serum $\mathrm{C} 4$ to be reduced significantly in 50 patients without null alleles (patient mean $0.24 \mathrm{~g} / 1$; control subject mean $0.34 \mathrm{~g} / 1)(p<$ 0.0001 ), although levels were lowest in the 13 patients with
\end{abstract}

one or more null alleles (mean $0.19 \mathrm{~g} / \mathrm{l}$ ). Finally, to examine the metabolic basis for the low concentrations of $\mathrm{C} 4$ and $\mathrm{C} 3$, the turnover of highly-purified, radiolabelled $\mathrm{C} 4$ and $\mathrm{C} 3$ was measured in seven recently diagnosed patients; four of these had low levels of $\mathrm{C} 4$. The data showed that three out of four of these patients had reduced synthesis of $\mathrm{C} 3$ and $\mathrm{C} 4$ and normal values for fractional catabolic rate. Two patients showed features of $\mathrm{C} 4$ hypercatabolism. We conclude that several early complement proteins are reduced in Type 1 diabetes, irrespective of duration or complications. These abnormalities may result from hypercatabolism or, more commonly reduction in protein synthesis. Genetic factors may influence the low serum concentration of $\mathrm{C} 4$.

Key words: Type 1 (insulin-dependent) diabetes, complement proteins, $\mathrm{C} 4$ allotypes, protein synthesis, hypercatabolism.
Several groups have reported abnormalities of the complement system in patients with Type 1 (insulin-dependent) diabetes. These include a high incidence of uncommon alleles of the components coded for by genes within the major histocompatibility complex, i.e. $C 2, C 4$ and $B[1,2]$ and an increased frequency of null alleles at the C4A locus [3-5]. Vergani and co-workers [6] have shown that approximately $25 \%$ of Type 1 patients have low $\mathrm{C} 4$ levels and Barnett et al. [7] have reported a correlation between reduced $\mathrm{C} 4$ concentration and the presence of microvascular complications.

However, non-genetic factors could contribute to the complement abnormalities observed in Type 1 diabetes. These factors include pathologic activators such as immune complexes which have been detected by many groups, using complement-dependent assays. It has been suggested that immune complex formation could play a role in the pathogenesis of long-term diabetic complications $[8,9]$ although this proposal remains contentious. Sundsmo and co-workers [10] have detected activation products of $\mathrm{C} 4, \mathrm{C} 3$ and $\mathrm{C} 5$ in the fresh plasma of a high percentage of Type 1 diabetic patients, but they did not attempt to relate this finding to the presence of immune complexes.

The established role of complement in both the enhancement and prevention of immunological inflammation makes it important to clarify the relative contribution of impaired synthesis and increased utilisation of complement proteins in Type 1 diabetes. To resolve this issue, we have examined components of each of the three major complement pathways, i. e., the classical and alternative pathways and the terminal membrane attack sequence. Four groups of subjects were examined: (a) patients with recently diagnosed Type 1 diabetes, (b) healthy first-degree relatives of this recent onset group, (c) patients with diabetes of more than 1-year duration without complications and (d) patients with documented retinopathy and/or nephropathy. The basis for the complement abnormalities was further clarified by $\mathrm{C} 4$ allotyping and by performing turnover studies with highly purified preparations of $\mathrm{C} 3$ and $\mathrm{C} 4$ in selected subjects. 
Table 1. Clinical and laboratory data on Type 1 (insulin-dependent) diabetic patients and their relatives

\begin{tabular}{|c|c|c|c|c|c|c|c|c|c|}
\hline Patients & Number & $\begin{array}{l}\text { Sex } \\
\text { (male:female) }\end{array}$ & $\begin{array}{l}\text { Age } \\
\text { (years) }\end{array}$ & $\begin{array}{l}\text { Duration } \\
\text { of diabetes } \\
\text { (years) }\end{array}$ & $\begin{array}{l}\text { Insulin } \\
\text { dose } \\
\left(\mathrm{U} \cdot \mathrm{kg}^{-1} \cdot \mathrm{day}^{-1}\right)\end{array}$ & $\begin{array}{l}\mathrm{HbA1} \\
(\%)\end{array}$ & $\begin{array}{l}\text { Blood } \\
\text { glucose } \\
(\mathrm{mmol} / \mathrm{l})\end{array}$ & $\begin{array}{l}\text { Retinopathy } \\
\text { background/ } \\
\text { prolif. }\end{array}$ & $\begin{array}{l}\text { Nephro- } \\
\text { pathy }\end{array}$ \\
\hline $\begin{array}{l}\text { Diabetes without } \\
\text { complications }\end{array}$ & 46 & $25: 21$ & $22 \pm 9$ & $10 \pm 7$ & $0.75 \pm 0.34$ & $12.2 \pm 2.5$ & $13.9 \pm 3.8$ & - & - \\
\hline Relatives & 43 & $23: 20$ & $21 \pm 14$ & - & - & - & - & - & - \\
\hline
\end{tabular}

Values given as mean \pm SD. Normal range for $\mathrm{HbA} 1=6.0-8.5 \%$

\section{Subjects and methods}

\section{Patients}

One hundred and eleven patients (59 males and 52 females) with Type 1 diabetes were selected for study. Their clinical data are shown in Table 1. Thirty-five recently diagnosed patients were investigated during their initial admission to hospital for stabilisation of blood glucose. Blood samples were taken after at least four days of insulin therapy. Onset of symptoms had occurred within the previous three months. Forty-three healthy first-degree relatives of these subjects were also studied at the time of the propositus' admission to hospital. These relatives represented one or more members of 19 families, each containing one patient with recently diagnosed Type 1 diabetes. They consisted of 28 parents and 15 siblings (mean age: 21 years; range: $7-47$ years).

Two groups with longer-duration diabetes were also studied: (a) 46 patients with a mean duration of diabetes of 10 years and without clinical or laboratory evidence of complications and (b) 30 patients with a mean duration of 18 years and with confirmed retinopathy and/or nephropathy (see Table 1). The majority of these subjects were attending a diabetes outpatient clinic while the rest were in hospital for stabilisation of their disease. All patients had been examined recently by a consultant ophthalmologist for evidence of retinopathy and had had regular measurements of serum creatinine and 24-h urine protein. Diabetic nephropathy was diagnosed when there was persistent proteinuria of $>300 \mathrm{mg} / 24 \mathrm{~h}$, irrespective of the level of serum creatinine. $\mathrm{HbA} 1$ was determined by a chromatographic technique, using a commercial kit (Bio-Rad Laboratories, Richmond, Calif, USA). The normal range was $6-8.5 \%$.

Patients and relatives with a history of recent infection, immunological disease or using pharmacological agents likely to affect immunological function were not considered for the study.

\section{Measurement of complement proteins}

The following complement components were measured by radial immuno-diffusion, using mono-specific antisera [11]: (1) classical pathway - Clq, r, s, C4 and C2 (2) alternative pathway - C3 and factor $\mathrm{B}$ (3) terminal membrane attack sequence - C5 and C6 (4) inhibitor proteins - $\mathrm{C} 1$ inhibitor, factors $\mathrm{I}$ and $\mathrm{H}$. Serum for these assays was obtained from a fresh blood sample and stored in liquid nitrogen until tested. The concentration of $\mathrm{C} 1 \mathrm{q}, \mathrm{C} 4$ and $\mathrm{C} 3$ was measured in $\mathrm{g} / \mathrm{l}$, while other components and inhibitors were expressed as a percentage of pooled normal human serum (NHS). All values were compared to those quantitated in 60 healthy control subjects. The antisera used for these assays had been shown to produce a single precipitin line against normal serum on double diffusion in agarose.

\section{C4 allotyping}

This was performed by the method described by Mauff and colleagues [12]. Briefly, plasma samples (in EDTA) were treated with

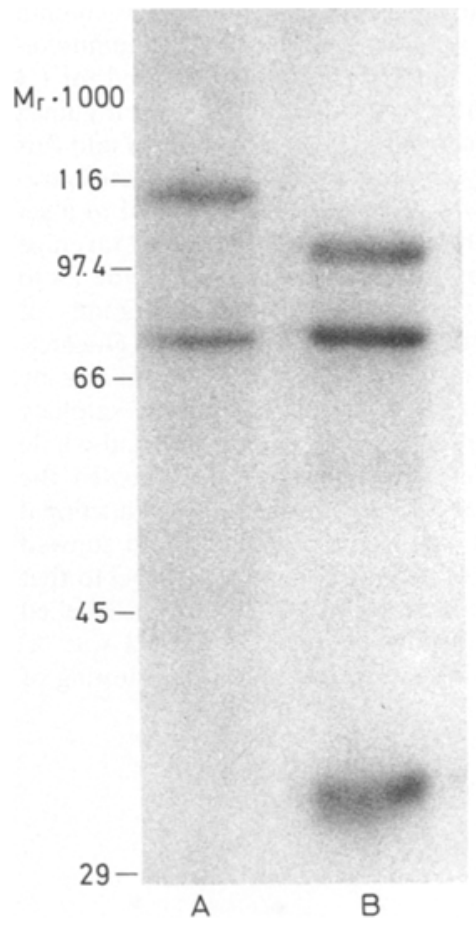

Fig. 1. Autoradiograph of polyacrylamide gel electrophoresis in sodium dodecyl sulphate under reducing conditions. Molecular weight markers are shown. The $\alpha$ and $\beta$ polypeptide chains of ${ }^{131} I-\mathrm{C} 3$ are shown in column $\mathrm{A}$ and the $\alpha, \beta$ and $\gamma$ chains of ${ }^{125} \mathrm{I}-\mathrm{C} 4$ are shown in column B. There are no significant radio-labelled contaminants

neuraminidase prior to electrophoresis in agarose and fixation with polyclonal anti-C4 (Silenus). A haemolytic overlay technique was used to distinguish $\mathrm{C} 4 \mathrm{~A}$ and $\mathrm{C} 4 \mathrm{~B}$ loci. Heterozygous null alleles were defined, where necessary by two dimensional electrophoresis using the same anti-C4 for the second stage [13].

\section{Detection of immune complexes}

These were detected by the fluid phase C1q binding assay [14]. Samples were taken at the same time as those for complement assays and $\mathrm{C} 4$ allotyping.

\section{Studies of the metabolism of purified C4 and C3}

Turnover studies were performed with highly-purified functionallyactive preparations of $\mathrm{C} 4$ and $\mathrm{C} 3$ in order to define the metabolic basis for the observed reduction in serum concentration of $\mathrm{C} 4$ and C3. Studies were performed in seven recently diagnosed Type 1 dia- 
betic patients, four of whom had serum $C 4>1$ SD below the mean level in normal subjects. These patients were in hospital for stabilisation of blood glucose and the initiation of diabetes education. At least one healthy age-matched control subject was studied with each patient. One subject with active systemic lupus erythematosus (SLE), a high level of immune complexes and demonstrable hypocomplementaemia was used as a positive control for both purified proteins.

$\mathrm{C} 3$ and $\mathrm{C} 4$ were prepared from fresh plasma (in EDTA) donated by laboratory staff who had been screened for hepatitis B surface antigen and HTLV-III antibody. All donors had the common C4A3,B1 allotype. The methods have been described in detail elsewhere [15]. Briefly, fresh plasma was made to $0.5 \mathrm{mmol} / 1$ with phenylmethylsulphonyl fluoride and precipitated with $12 \%(\mathrm{w} / \mathrm{v})$ polyethylene glycol 4000 at $4^{\circ} \mathrm{C}$. The protein pellet was dissolved in buffer $(100 \mathrm{mmol} / 1$ $\mathrm{K}_{2} \mathrm{HPO} 4,150 \mathrm{mmol} / \mathrm{l} \mathrm{NaC} 1,5 \mathrm{mmol} / 1 \mathrm{Na} 2 \mathrm{EDTA}$ and $5 \mathrm{mmol} / 1$ benzamidine $\mathrm{HCL}, \mathrm{pH} 7.4$ ) and run onto a $2.5 \times 5 \mathrm{~cm}$ lysine-sepharose $4 \mathrm{~B}$ column in order to deplete plasminogen. Fractions were pooled and loaded onto a diethylaminoethyl-sephadex-A50 column $(5 \times 10 \mathrm{~cm})$ with elution of $\mathrm{C} 4$ by linear gradient of six column volumes from $0.1 \mathrm{~mol} / 1-0.4 \mathrm{~mol} / \mathrm{l} \mathrm{NaC} 1$. Fractions were tested for $\mathrm{C} 4$ haemolytic activity using a standard assay with C4-deficient guinea pig serum [16]. Haemolytically active fractions were pooled and further precipitated with solid polyethylene glycol to a final concentration of $20 \%(\mathrm{w} / \mathrm{v})$. The pellet was re-dissolved and applied to a sepharose $\mathrm{CL} 6 \mathrm{~B}$ column $(2.5 \times 100 \mathrm{~cm})$. The final $\mathrm{C} 4$ pool (average volume $100 \mathrm{ml}$ ) was concentrated by dialysis against Aquacide $1 \mathrm{~A}$ to approximately $40 \mathrm{ml}$, thus yielding a C4 concentration of $0.5-0.8 \mathrm{mg} / \mathrm{ml}$. Final preparations were tested for purity by Ouchterlony double diffusion against an anti-whole human serum and by polyacrylamide gel electrophoresis in sodium dodecyl sulphate (PAGE-SDS). Each protein showed a single line against anti-whole serum while PAGE-SDS, under reducing conditions showed the three polypeptide chains of $\mathrm{C} 4$ and the two chains of $\mathrm{C} 3$. Functional activity was tested by standard haemolytic techniques and showed both proteins to have comparable activity (i.e., at least $80 \%$ ) to that observed in an equivalent concentration of NHS. C4 was labelled with ${ }^{125} \mathrm{I}$, using the lactoperoxidase technique [17] and $\mathrm{C} 3$ was labelled with ${ }^{131} \mathbf{I}$ using a chloramine T method [18]. Further testing of

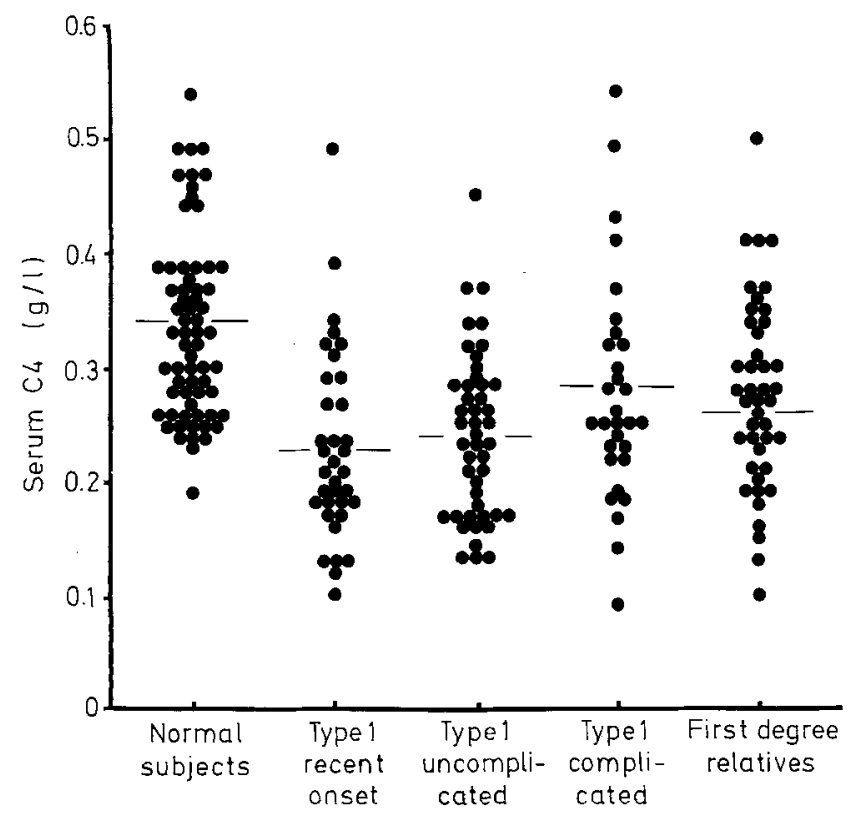

Fig. 2. Serum $\mathrm{C} 4$ concentration $(\mathrm{g} / \mathrm{l})$ in control subjects and patients in each study group. Means are shown by horizontal bars. There was significant reduction of $\mathrm{C} 4$ in (a) patients with recent onset Type 1 diabetes $(p<0.001)$, (b) patients with $(p<0.01)$ and without $(p<$ $0.001)$ diabetic complications and (c) healthy first-degree relatives of the recent onset group $(p<0.001)$ functional activity showed that iodination had caused no significant loss of haemolytic activity and autoradiography of PAGE-SDS confirmed that there was no significant amount of radio-labelled contaminants or breakdown products (Fig.1).

Both proteins were sterilised by Millipore filtration $(0.22 \mu \mathrm{mol} / 1)$, cultured for aerobic and anaerobic organisms and pyrogen-tested in rabbits. Each patient received approximately $10 \mu \mathrm{Ci}$ of ${ }^{125} \mathrm{I} . \mathrm{C} 4$ and $2.5 \mu \mathrm{Ci}$ of ${ }^{131} \mathrm{I} . \mathrm{C} 3$ intravenously after blockade of thyroidal uptake by the administration of oral potassium iodide $(180 \mathrm{mg} /$ day) for 3 days. The turnover protocol had been approved previously by the hospital Ethics Committee and written informed consent was obtained from each patient. Plasma samples (in EDTA) were taken at $15 \mathrm{~min}, 6 \mathrm{~h}, 24 \mathrm{~h}$ and twice daily until there was less than $8 \%$ residual plasma radioactivity. Twenty-four h samples of urine were collected throughout the study period. Metabolic parameters were calculated from plasma and urine data by (a) metabolic clearance [19], whereby the fractional catabolic rate $(\mathrm{FCR})$ is calculated as the ratio of total urinary radioactivity $/ 24 \mathrm{~h}$ to the mean protein-bound plasma radioactivity and then expressed as \% plasma pool radioactivity $/ \mathrm{h}$ and (b) integrated rate equations analysis [20]. This method uses measurements of plasma and urinary radioactivity to derive values for extravascular radioactivity and to solve equations where the slopes represent FCR and extravascular/intravascular distribution. Synthesis rate $\left(\mathrm{mg} \cdot \mathrm{kg}^{-1} \cdot \mathrm{h}^{-1}\right)$ was derived from the formula:

serum concentration $(\mathrm{mg} / \mathrm{ml}) \times$ plasma volume $(\mathrm{ml}) \times \mathrm{FCR}(\% / \mathrm{h})$

$$
\text { weight }(\mathrm{kg})
$$

Serum $\mathrm{C} 3$ and $\mathrm{C} 4$ levels were measured at the beginning and end of each turnover to confirm a steady state.

\section{Statistical analysis}

The normal range for each complement component was established by the analysis of sera from 60 age-matched healthy control subjects. Differences in serum concentration were analysed by a Student's ttest and by a Wilcoxon Rank Sum Test. This latter test was required for the analysis of $\mathrm{C} 4$ data, as $\mathrm{C} 4$ concentration in normal subjects may not have a normal distribution.

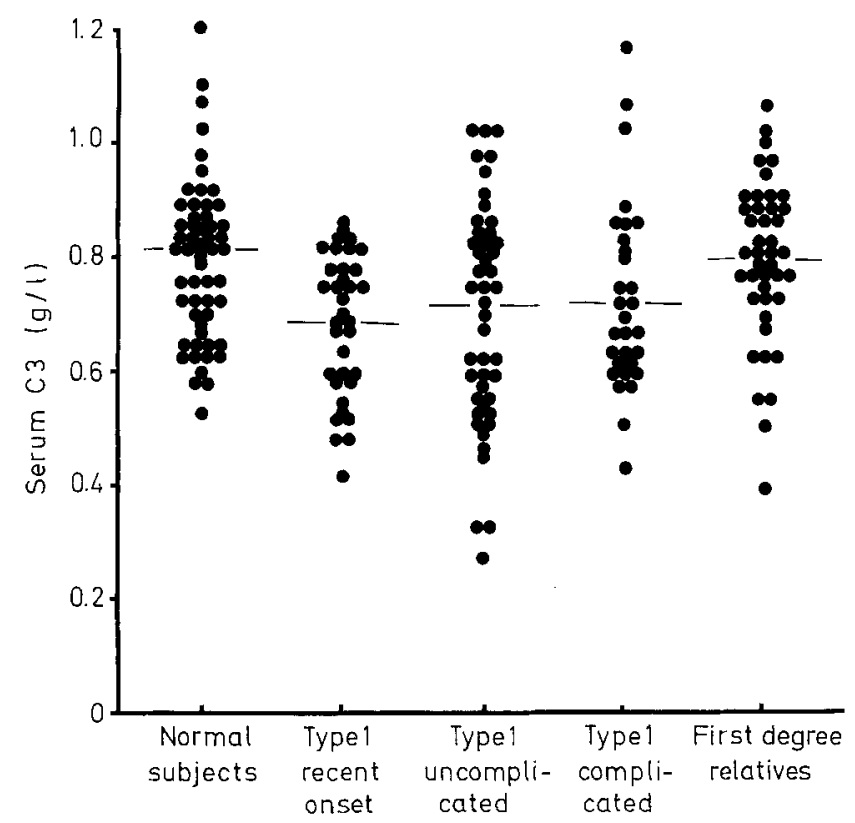

Fig.3. Serum C3 concentration in control subjects and patients in each study group. Means are shown by horizontal bars. There was significant reduction of $\mathrm{C} 3$ in (a) patients with recent onset Type 1 diabetes $(p<0.001)$ and (b) patients with $(p<0.05)$ and without $(p<0.001)$ diabetic complications 
Table 2. Serum concentration of classical and alternative pathway complement proteins in Type 1 (insulin-dependent) diabetic patients and their relatives

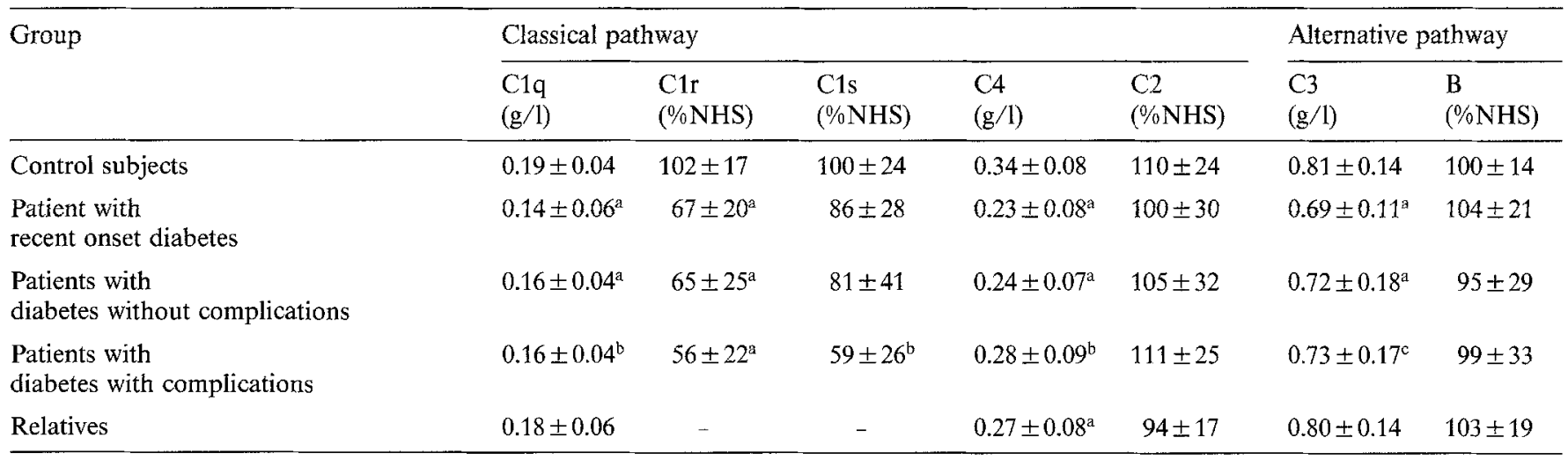

Values are given as mean $\pm \mathrm{SD}$; NHS $=$ pooled normal human serum. ${ }^{\mathrm{a}} p<0.001,{ }^{\mathrm{b}} p<0.01,{ }^{\mathrm{c}} p<0.05$ when compared to control subjects

Table 3. Serum concentration of complement inhibitors and terminal attack sequence proteins in Type 1 (insulin-dependent) diabetic patients and their relatives

\begin{tabular}{|c|c|c|c|c|c|}
\hline \multirow[t]{2}{*}{ Group } & \multicolumn{2}{|c|}{$\begin{array}{l}\text { Terminal attack } \\
\text { sequence }\end{array}$} & \multicolumn{3}{|l|}{ Inhibitors } \\
\hline & $\begin{array}{l}\mathrm{C} 5 \\
(\% \mathrm{NHS})\end{array}$ & $\begin{array}{l}\text { C6 } \\
(\% \mathrm{NHS})\end{array}$ & $\begin{array}{l}\text { C1-Inhib. } \\
\text { (\%NHS) }\end{array}$ & $\begin{array}{l}\text { I } \\
\text { (\%NHS) }\end{array}$ & $\begin{array}{l}\mathrm{H} \\
(\% \mathrm{NHS})\end{array}$ \\
\hline $\begin{array}{l}\text { Control } \\
\text { subjects }\end{array}$ & $101 \pm 18$ & $103 \pm 19$ & $91 \pm 14$ & $95 \pm 15$ & $93 \pm 15$ \\
\hline $\begin{array}{l}\text { Patients with } \\
\text { recent onset } \\
\text { diabetes }\end{array}$ & $103 \pm 19$ & $109 \pm 25$ & $115 \pm 31$ & $91 \pm 25$ & $83 \pm 22$ \\
\hline $\begin{array}{l}\text { Patients with } \\
\text { diabetes } \\
\text { without } \\
\text { complications }\end{array}$ & $105 \pm 38$ & $95 \pm 33$ & $122 \pm 34$ & $94 \pm 31$ & $87 \pm 25$ \\
\hline $\begin{array}{l}\text { Patients with } \\
\text { diabetes with } \\
\text { complications }\end{array}$ & $120 \pm 32$ & $87 \pm 38$ & $120 \pm 28$ & $102 \pm 23$ & $96 \pm 23$ \\
\hline Relatives & $103 \pm 26$ & $100 \pm 21$ & $106 \pm 26$ & $95 \pm 20$ & $96 \pm 17$ \\
\hline
\end{tabular}

Values are given as mean $\pm \mathrm{SD}$; NHS $=$ pooled normal human serum

C4 allotype data were divided into two groups: (a) those subjects showing homozygous or heterozygous null at either locus and (b) subjects without detectable null alleles. The difference in concentration of $\mathrm{C} 4$ between each group was analysed by a Student's t-test and the Wilcoxon test.

Linear regression analysis, with calculation of the coefficient ' $r$ ', was used to examine correlations between the level of immune complexes and the concentration of $\mathrm{C} 1 \mathrm{q}, \mathrm{C} 4, \mathrm{C} 2$ and $\mathrm{C} 3$ and between $\mathrm{HbA} 1$ and the serum level of $\mathrm{C} 4$ and $\mathrm{C} 3$. A $p$ value of $<0.05$ was considered statistically significant.

\section{Results}

\section{Complement proteins}

These data are shown in Figures 2 and 3 and Tables 2 and 3 . There was a highly significant reduction in serum $\mathrm{C} 1 \mathrm{q}, \mathrm{C} 4$ and $\mathrm{C} 3$ in patients with recently diagnosed Type 1 diabetes compared to control subjects $(p<0.001$ for each protein - unpaired t-test; $p<0.001$ - Wilcoxon test for C4). These three components were also reduced in both groups of longer-duration patients: uncomplicated $-p<0.001$ for each protein; complicated $-p<0.01 ; p<0.01$ and $p<0.05$ respectively. The $\mathrm{C} 4$ concentration was also reduced in firstdegree relatives $(p<0.001)$ but there was no difference between the level in parents and siblings (mean $\pm \mathrm{SD}$ : $0.26 \pm 0.08$ and $0.28 \pm 0.09 \mathrm{~g} / 1$ respectively). There were no significant abnormalities of other complement components (i.e., C2, B, C5, C6 and inhibitors).

A comparison of complement levels in each patient group showed $\mathrm{C} 4$ to be significantly lower in the recent onset patients than in those with diabetic complications $(p<0.05)$. There was no difference in C4 levels in sub-groups of longer-standing patients (i.e., with and without complications) even when matched for duration of diabetes. In view of the significant reduction in $\mathrm{C} 1 \mathrm{q}$, other components of the $\mathrm{C} 1$ macromolecule were also measured; these data are shown in Table 2. C1r was significantly reduced in each patient group $(p<0.001)$ while C1s was low only in the patients with complications $(p<0.01)$. No correlation was observed between HbA1 and the serum concentration of $\mathrm{C} 3$ and $\mathrm{C} 4$.

\section{Detection of immune complexes}

Three of the recently diagnosed patients and eight of those with longer-duration disease had detectable immune complexes. However, there were no differences between the level in 60 control subjects and that observed in each study group. There was also no correlation between the concentration of C1q, C4, C2 or C3 and the level of immune complexes.

\section{C4 allotypes}

The analysis of C4A and C4B alleles in 63 patients (selected from each of the study groups) showed 13 (i.e., $21 \%$ ) to have one or more null alleles. Ten involved the 
A locus (five with a single null and five with homozygous $\mathrm{C} 4 \mathrm{~A} 0$ ) and three involved the $\mathrm{B}$ locus (one with homozygous $\mathrm{C} 4 \mathrm{~B} 0$ ). A comparison of $\mathrm{C} 4$ levels in con-

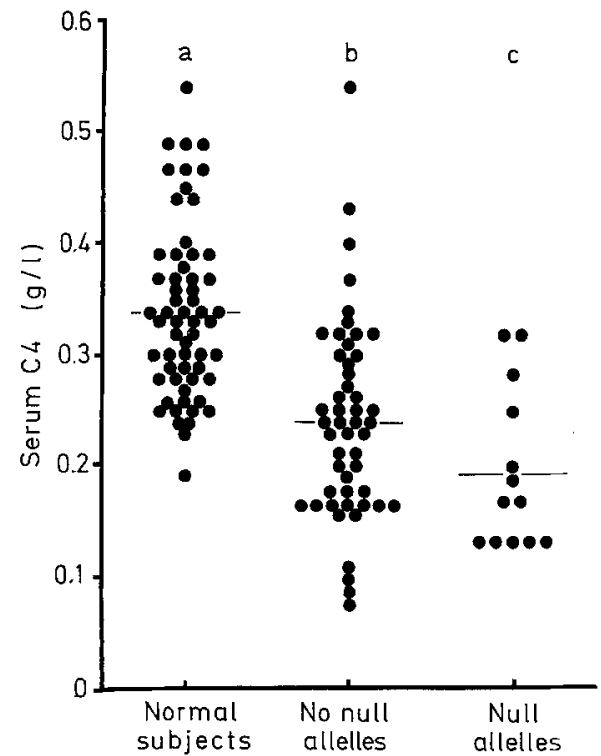

Fig. 4. Serum $\mathrm{C} 4$ concentration in (a) control subjects, (b) patients with Type 1 diabetes without null alleles and (c) patients with one or more null alleles. Means are shown by horizontal bars. There was a highly significant difference between control subjects $(0.34 \pm$ $0.08 \mathrm{~g} / \mathrm{l}$; mean $\pm \mathrm{SD})$ and each patient group $(0.24 \pm 0.09$ and $0.19 \pm 0.08 \mathrm{~g} / 1$, respectively), $(p<0.0001)$. There was also a significant difference between patients with and without null alleles $(p<$ $0.05)$ trol subjects, patients without detectable null alleles and those with one or more null alleles are shown in Figure 4 . There was a highly significant difference between the concentration in controls $(0.34 \pm 0.08 \mathrm{~g} / 1$; mean $\pm \mathrm{SD})$ and that in patients without null alleles $(0.24 \pm 0.09 \mathrm{~g} / 1 ; t=6.33 ; p<0.0001)$. There was also a difference between patients with $(0.19 \pm 0.08 \mathrm{~g} / 1)$ and without null alleles $(p<0.05)$.

\section{Studies of C4 and C3 metabolism}

These data are summarised in Tables 4 and 5. Patients 1 and 7, with normal serum C4 and C3, had normal values for FCR and synthesis of both proteins. Three of the other five patients had normal FCR-C4, while patients 4 (Fig. 5) and 6 had reduced T1/2-C4 (38 and $44 \mathrm{~h}$ ) and increased FCR-C4 $(2.30$ and $2.54 \% / \mathrm{h})$ respectively. $\mathrm{C} 4$ synthesis was normal in these two patients but reduced in the other three (i.e., patients 2,3 and 5) with low/normal levels of serum $\mathrm{C} 4$; each of these latter three patients had a common allotype, without detectable null alleles. No significant abnormalities of $\mathrm{C} 4$ distribution were observed.

Values for FCR-C3 were normal in six out of seven patients; patient 6 had an FCR of $2.25 \% / \mathrm{h}$. Two other subjects had reduced C3 synthesis. Notably, the three patients with low C4 synthesis also had the lowest levels of $\mathrm{C} 3$ production. (There was close correlation between the two methods of calculation of metabolic parameters.)

Table 4. Half life, fractional catabolic rate and synthesis rate for ${ }^{125} \mathrm{I} . \mathrm{C} 4$ in recent onset Type 1 diabetic patients and control subjects

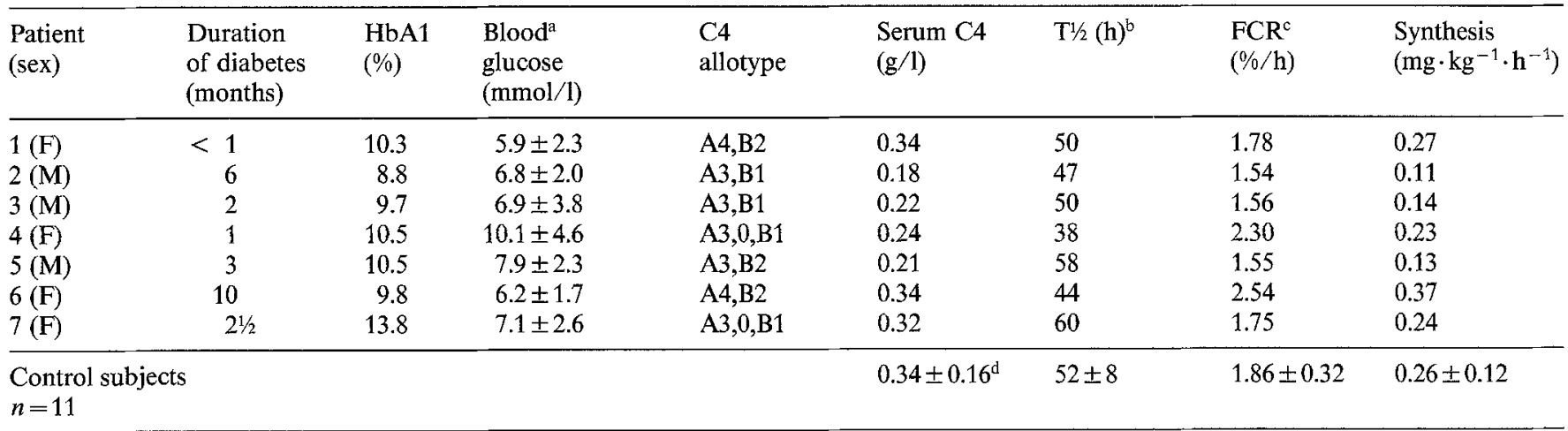

${ }^{a}$ mean $\pm \mathrm{SD}$ of twice daily measurements performed during metabolic study; ${ }^{\mathrm{b}}$ half life; ${ }^{\mathrm{c}}$ fractional catabolic rate ${ }^{\mathrm{d}}$ mean $\pm 2 \mathrm{SD}$

Table 5. Half life, fractional catabolic rate and synthesis rate for ${ }^{131} \mathrm{I} . \mathrm{C} 3$ in recent onset Type 1 diabetic patients and control subjects

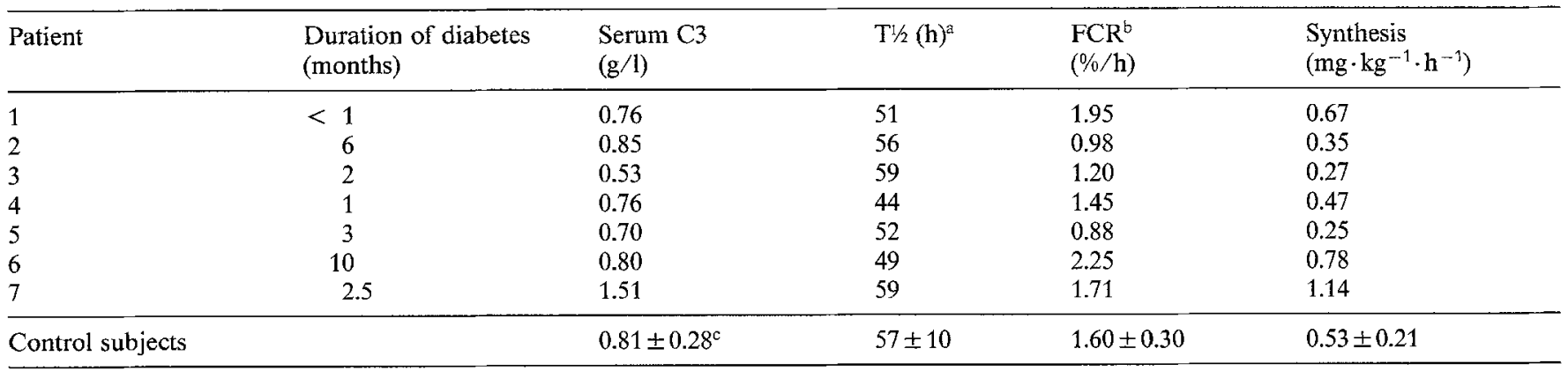

${ }^{a}$ Half life; ${ }^{b}$ fractional catabolic rate; ${ }^{c}$ mean $\pm 2 S D$ 


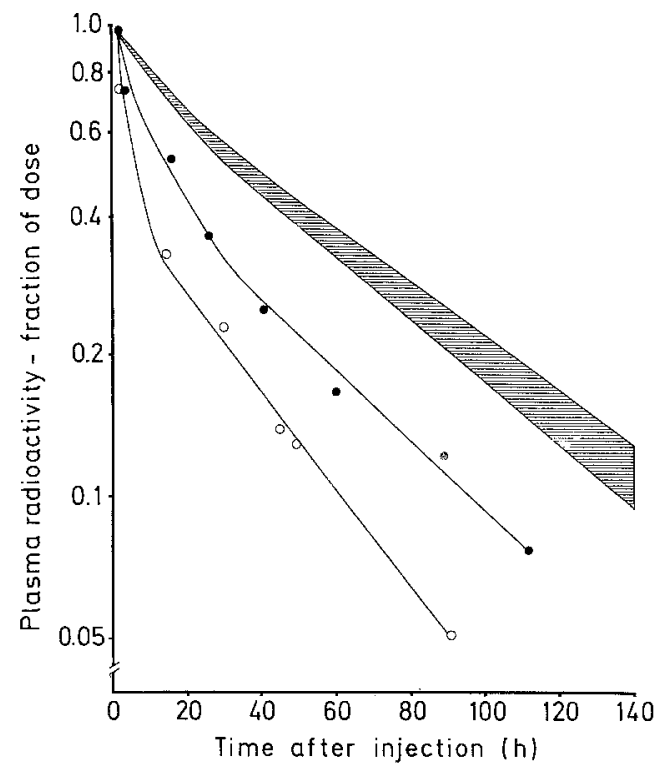

Fig. 5. Plasma disappearance curves for ${ }^{125} \mathrm{I}-\mathrm{C} 4$ in 11 control subjects (shaded), a patient with recent onset Type 1 diabetes $(\bullet)$ (patient 4, Table 4) and a patient with active systemic lupus erythematosus $(O)$. The normal half-life was $52 \pm 8 \mathrm{~h}$ (mean $\pm 2 \mathrm{SD}$ ) with a fractional catabolic rate of $1.86 \pm 0.32 \% / \mathrm{h}$. The diabetic patient had a half-life of $38 \mathrm{~h}$ and a fractional catabolic rate of $2.30 \% / \mathrm{h}$ while the patient with systemic lupus erythematosus had a half-life of $30 \mathrm{~h}$ and a fractional catabolic rate of $3.20 \% / \mathrm{h}$

The patient with active SLE showed decreased $\mathrm{T}^{1 / 2}$ for both $\mathrm{C} 4$ and $\mathrm{C} 3$ ( 30 and $36 \mathrm{~h}$ ) with increased values for FCR (3.20 and $3.42 \% / \mathrm{h}$ respectively). The $\mathrm{C} 4$ plasma disappearance curve for this patient is shown in Figure 5.

\section{Discussion}

Our data demonstrate abnormalities of three early components of the complement system in patients with Type 1 diabetes. These changes occurred in both recently diagnosed patients and those with long-duration disease, irrespective of complications. Low levels of $\mathrm{C} 4$ in Type 1 diabetes have been reported previously $[3,6$, 7] but we also found a highly significant reduction in serum $\mathrm{C} 1 \mathrm{q}$ and $\mathrm{C} 3$. While there have been no previous reports of measurements of $\mathrm{C} 1 \mathrm{q}$ in this disease, Vergani and co-workers [6] found that the frequency of low C3 levels in Type 1 diabetic patients was comparable to that in Type 2 (non-insulin-dependent) diabetic patients. However, the actual quantitation of $\mathrm{C} 3$ levels and their comparison to a control group was not reported.

This pattern of complement abnormality usually reflects activation of the classical pathway, either by immune complexes or IgG or IgM class of antibody. It is established that a high percentage of patients with diabetes, irrespective of type, have detectable immune complexes $[8,21]$ although our data show no correlation between their level - as measured by a C1q-de- pendent assay - and the concentration of individual complement components. Nevertheless, several observations suggest that immune complexes may have contributed to the observed complement abnormalities: firstly, individual immune complex assays may fail to detect specific antigen/antibody systems; secondly, two of our (recently diagnosed) patients showed $\mathrm{C} 4$ hypercatabolism which is consistent with immune complex-mediated complement activation; and thirdly, we have observed a significant rise in $\mathrm{C} 4$ concentration in some patients when studied 3-6 months after diagnosis (unpublished data). The finding of normal concentrations of C1q, C4 and C3 in Type 2 diabetes [21] argues against the possibility that poor glucose control at the time of diagnosis contributed to the reduction in serum complement levels. Moreover, it is not surprising to find normal values for several complement components despite significant reduction in $\mathrm{C} 1 \mathrm{q}, \mathrm{r}, \mathrm{C} 4$ and C3. This difference may reflect the variable metabolic response of individual complement proteins. For example, Sissons and co-workers [22] have shown that C5 exhibits significantly less hypercatabolism than C3 in patients with immune complex disease and hypocomplementaemia.

We found that $\mathrm{C} 4$ levels were also reduced in healthy relatives which supports the view that inherited factors contribute, at least in part, to the $\mathrm{C} 4$ abnormality. Our data confirm that $\mathrm{C} 4$ was lower in patients with detectable null alleles $(p<0.05)$ (see Fig. 4 ), and Uko and co-workers [23] have quantitated the influence of these defects on $\mathrm{C} 4$ concentration. However, we also found a significant difference between control subjects and those Type 1 patients where $\mathrm{C} 4$ null alleles were not found. This was despite the fact that our 60 control subjects were selected without regard for $\mathrm{C} 4$ allotype.

Our turnover studies suggest that reduction in protein synthesis was a major influence on the level of $\mathrm{C} 3$ and $\mathrm{C} 4$. This is in contrast to other immune complexassociated diseases, such as systemic lupus erythematosus (SLE) [24] and rheumatoid arthritis [25] where hypercatabolism and compartmental redistribution contribute significantly to the low complement levels. Previous reports of $\mathrm{C} 4$ metabolism show metabolic parameters similar to ours; however, those studies were hindered by reduction in functional activity of the purified protein and subsequent evidence of denaturation on turnover analysis $[25,26]$. In our study, five out of seven patients had a normal half-life and fractional catabolic rate for $\mathrm{C} 4$ while these parameters were normal for $\mathrm{C} 3$ in six patients. Three out of the four subjects with a C4 level >1SD below the normal mean showed reduced synthesis of this component and these three patients also had the lowest values for $\mathrm{C} 3$ synthesis. Notably, each had a common $\mathrm{C} 4$ allotype (see Table 4). The two patients with $\mathrm{C} 4$ hypercatabolism (one with $\mathrm{C} 4 \mathrm{~A} 3,0$ ) showed linear disappearance of plasma radioactivity beyond $90 \%$ of the injected dose of radiolabelled protein. This argues against the possi- 
bility that significant amounts of radiolabelled $\mathrm{C} 4$ breakdown products were generated during the course of the turnover study, and the simultaneous examination of a normal control emphasised the significance of the metabolic abnormalities observed in these two patients. Furthermore, there were no detectable radiolabelled breakdown proteins prior to injection (see Fig.1). Previous studies (with C3 and B) demonstrate that patients with high levels of activation products show a non-linear plasma disappearance curve [24].

The basis for the defect in synthesis of $\mathrm{C} 4$ and $\mathrm{C} 3$ is uncertain, apart from the demonstrable influence of $\mathrm{C} 4$ null alleles on the concentration of the fourth component. Failure of insulin synthesis might influence hepatic protein production and therefore affect the level of those complement proteins produced by the liver. However, two observations make this unlikely: firstly, the selective involvement of $\mathrm{C} 4$ and $\mathrm{C} 3$, without reduction in other components such as B, C5 and C6 (all of which are synthesised by hepatocytes) and secondly, the persistence of the defect in long-standing disease.

The biosynthesis and intracellular processing of $\mathrm{C} 3$ and $\mathrm{C} 4$ are similar and the plasma products share several structural and functional properties. It is known that pro-C4 undergoes several modifications prior to secretion and that these include glycosylation, which has been shown to alter intracellular catabolism [27]. Several pieces of evidence suggest that genes other than those residing in the major histocompatibility complex may contribute to the control of $\mathrm{C} 4$ production. For example, it has been shown that additional genetic factors are responsible for the post-translational modification of pro-C4 [28]. Also, Muir and coworkers [29] have reported incomplete $\mathrm{C} 4$ deficiency in a patient with SLE and six healthy family members; the defect showed no linkage to HLA, Bf or C4 structural loci. (The proband's allotype was $\mathrm{C} 4 \mathrm{~A} 3,0 ; \mathrm{B} 1,2$ despite a $\mathrm{C} 4$ concentration of $2-5 \%$ normal). Finally, a high percentage of patients with juvenile chronic active hepatitis and their relatives have been reported to have low C4 levels [30]; these patients showed no evidence of complement activation nor defects in hepatic synthesis of albumin and transferin. Despite a high incidence of $\mathrm{C} 4$ null alleles, it was suggested that the low $\mathrm{C} 4$ levels resulted partially from non-HLA genetic influences. Our data do not clarify the basis for the reduction in components of the $\mathrm{C} 1$ macromolecule. In contrast to $\mathrm{C} 3$ and $\mathrm{C} 4$, the site(s) of production of these three subunits are less well-understood. It seems probable that the bulk of plasma $\mathrm{C} 1 \mathrm{q}, \mathrm{r}, \mathrm{s}$, arises from gastrointestinal and genitourinary epithelial cells. It is notable that each of the subunits was reduced (to a variable extent) in patients with Type 1 diabetes. This is in contrast to patients with immune complex-induced complement activation where levels of C1s and $\mathrm{C} 1 \mathrm{r}$ are usually normal despite reduction (through hypercatabolism) in C1q. The restriction of the abnormality to the patient groups suggests that the diabetic state per se is responsible for the defect(s) in C1 (and C3). However, the finding of normal complement levels in Type 2 diabetes makes it unlikely that the metabolic disturbance is primarily responsible for the changes in complement proteins.

We did not establish whether the observed complement abnormalities caused alteration in complement function in vitro. Recent studies show that allotypic differences in $\mathrm{C} 4$ may affect protective complement mechanisms, such as the inhibition of immune precipitation. Schifferli and co-workers [31] showed that proteins of the C4A gene were 1.7 times more efficient in this regard than $\mathrm{C} 4 \mathrm{~B}$ products. (This is in contrast to studies of red cell lysis where C4B-derived products show greater activity.) They suggested that C4A proteins may be involved predominately in immune clearance reactions, and this proposal could be important in Type 1 diabetes where there is an increased incidence of C4A null. Several other publications show that relatively subtle defects of $\mathrm{C} 4 \mathrm{~A}$ and/or $\mathrm{C} 4 \mathrm{~B}$ (i.e., 1, 2 or 3 nulls) may be associated with an increased incidence of auto-immune disease [29, 30, 32]. This concomitant defect in $\mathrm{C} 1$ and $\mathrm{C} 3$ in our patients could further influence functions mediated by these early complement components. For example, the subunits of $\mathrm{C} 1$ are essential for binding of immune aggregates (i.e., C1q) and subsequent initiation of classical pathway activation (i.e., C1r, s), while $\mathrm{C} 3$ is required for assembly of the alternative pathway converting enzyme, $\mathrm{C} 3 \mathrm{~b}, \mathrm{Bb}$ and its involvement in solubilisation of antigen/antibody complexes.

In conclusion, our data show significant reduction in the early complement components $\mathrm{C} 1, \mathrm{C} 4$ and $\mathrm{C} 3$ in patients with Type 1 (insulin-dependent) diabetes, irrespective of duration. The abnormalities of $\mathrm{C} 1$ and $\mathrm{C} 3$ were confined to Type 1 patients while low $\mathrm{C} 4$ levels were also seen in healthy first-degree relatives. However, significant $\mathrm{C} 4$ reduction occurred independently of null alleles at $\mathrm{C} 4$ genetic loci. Metabolic studies showed that the low levels of $\mathrm{C} 4$ and $\mathrm{C} 3$ resulted from reduction in synthesis in three patients, while two showed hypercatabolism. The data suggest that the diabetic state per se is responsible for reduced production of $\mathrm{C} 1$ subunits, $\mathrm{C} 3$ and possibly $\mathrm{C} 4$.

Acknowledgements. This study was supported by research grants from the National Health and Medical Research Council of Australia and the Rebecca L. Cooper Research Foundation. We wish to thank Professor G. Antony and Drs. W. Kidson and S.Colagiuri for allowing us to study their patients.

\section{References}

1. Raum D, Stein R, Alper CA, Gabbay KH (1979) Genetic marker for insulin-dependent diabetes mellitus. Lancet 1: 1208-1210

2. Wolf E, Cudworth AG, Marwick JR, Wells L, Bodansky HJ, Gorsuch AN, Spencer KM, Lister J (1981) Bf and C2 complement factors in Type 1 diabetes. Diabetologia 20: 667 (Abstract) 
3. Dawkins RL, Uko G, Christiansen FT, Kay PH (1983) Low C4 concentrations in insulin dependent diabetes mellitus. $\mathrm{Br}$ Med $\mathrm{J}$ 287: 839

4. McCluskey J, McCann VJ, Kay PH, Zilko PJ, Christiansen FT, O'Neill GJ, Dawkins RL (1983) HLA and complement allotypes in Type 1 (insulin-dependent) diabetes. Diabetologia 24: 162-165

5. Mijovic C, Fletcher J, Bradwell AR, Harvey T, Barnett AH (1985) Relation of gene expression (allotype) of the fourth component of complement to insulin dependent diabetes and its microangiopathic complications. Br Med J 291: 9-10

6. Vergani D, Johnston C, B-Abdullah N, Barnett AH (1983) Low serum $\mathrm{C} 4$ concentrations: an inherited predisposition to insulin dependent diabetes? Br Med J 286: 926-928

7. Barnett AH, Mijovic C, Fletcher J, Chesner I, Kulkuska-Langlands BM, Holder R, Bradwell AR (1984) Low plasma C4 concentrations: association with microangiopathy in insulin dependent diabetes. Br Med J 289: 943-945

8. DiMario U, Iavicoli M, Andreani D (1980) Circulating immune complexes in diabetes. Diabetologia 19: 89-92

9. Brownlee M, Pongor S, Cerami A (1983) Convalent attachment of soluble proteins by nonenzymatically glycosylated collagen. Role in the in situ formation of immune complexes. J Exp Med 158: $1739-1744$

10. Sundsmo JS, Papin RA, Wood L, Hirani S, Waldeck N, Buckingham B, Kershnar A, Ascher M, Charles MA (1985) Complement activation in Type 1 human diabetes. Clin Immunol Immunopathol 35: 211-225

11. Mancini G, Carbonara AL, Heremans JF (1965) Immunochemical quantitation of antigens by single radial immunodiffusion. Immunochemistry 2: 235-254

12. Mauff G, Alper CA, Awdeh Z, Batchelor JR, Bertrams J, BruunPetersen G, Dawkins RL, Demant P, Edwards J, GrosseWilde H, Hauptmann G, Klouda P, Lamm L, Mollenhauer E, Nerl C, Olaisen B, O'Neill G, Rittner C, Roos MH, Skanes V, Teisberg P, Wells L (1983) Statement on the nomenclature of human C4 allotypes. Immunobiology 164: 184-191

13. Awdeh ZL, Raum D, Alper CA (1979) Genetic polymorphism of human complement $\mathrm{C} 4$ and detection of heterozygotes. Nature 282: 205-207

14. Zubler RH, Lange G, Lambert PH, Miescher PA (1976) Detection of immune complexes in unheated sera by a modified ${ }^{125}$ I.C1q binding test. J Immunol 116: 232-235

15. Whaley K (1985) Purification of complement components and preparation of antisera. In: Whaley $\mathrm{K}$ (ed) Methods in complement for clinical immunologists. Churchill Livingstone, London, pp 21-76

16. Gaither TA, Alling DW, Frank MM (1974) A new one-step method for the functional assay of the fourth component (C4) of human and guinea pig complement. J Immunol 113: 574-583

17. Marchalonis JJ (1969) An enzymic method for trace iodination of immunoglobulins and other proteins. Biochem J 113: 299-305

18. McConahey PJ, Dixon FJ (1966) A method of trace iodination of proteins for immunologic studies. Int Arch Allergy Appl Immunol 29: 185-189

19. Berson SA, Yalow RS (1957) Distribution and metabolism of ${ }^{131} \mathrm{I}-$ labelled proteins in man. Fed Proc 16: 13s-18s

20. Nosslin B (1972) Analysis of disappearance time curves after single injection of labelled proteins. In: Protein Turnover Ciba
Foundation Symposium 9. Elsevier/North Holland, Amsterdam, pp 113-120

21. Charlesworth JA, Campbell LV, Catanzaro R, Pussell BA, Pasterfield GV, Peake P (1982) Immune complexes in diabetes mellitus: studies of complement utilisation and tissue deposition. J Clin Lab Immunol 8: 163-168

22. Sissons JGP, Leibowitch J, Amos N, Peters DK (1977) Metabolism of the fifth component of complement, and its relation to metabolism of the third component, in patients with complement activation. J Clin Invest 59: 704-715

23. Uko G, Christiansen FT, Dawkins RL, McCann VJ (1986) Reference ranges for serum $\mathrm{C} 4$ concentrations in subjects with and without C4 null alleles. J Clin Pathol 39: 573-576

24. Charlesworth JA, Gwyn Williams D, Sherington E, Lachmann JP, Peters DK (1974) Metabolic studies of the third component of complement and the glycine-rich beta glycoprotein in patients with hypocomplementemia. J Clin Invest 53:1578-1587

25. Kaplan RA, Curd JG, Deheer DH, Carson DA, Pangburn MK, Muller-Eberhard JH, Vaughan JH (1980) Metabolism of C4 and Factor B in theumatoid arthritis - Relation to rheumatoid factor. Arthritis Rheum 23: 911-920

26. Ruddy S, Carpenter CB, Chin KW, Knostman JN, Soter NA, Gotze O, Muller-Eberhard HJ, Austen KF (1975) Human complement metabolism: An analysis of 144 studies. Medicine (Baltimore) $54: 165-178$

27. Matthews $\mathrm{J}_{\mathbf{r}} \mathrm{WJ}$, Goldberger G, Marino Jr JT, Einstein LP, Gash DJ, Colten HR (1982) Complement proteins C2, C4 and factor B - Effect of glycosylation on their secretion and catabolism. Biochem J 204: 839-846

28. Karp DR, Atkinson JP, Shreffler DC (1982) Genetic variation in glycosylation of the fourth component of murine complement. Association with haemolytic activity. J Biol Chem 257: $7330-7335$

29. Muir WA, Hedrick S, Alper CA, Ratnoff OD, Schacter B, Wisnieski JJ (1984) Inherited incomplete deficiency of the fourth component of complement (C4) determined by a gene not linked to human histocompatibility leukocyte antigens. J Clin Invest 74: 1509-1514

30. Vergani D, Wells L, Larcher VF, Nasaruddin BA, Davies ET, Mieli-Vergani G, Mowat AP (1985) Genetically determined low C4: a predisposing factor to autoimmune chronic active hepatitis. Lancet 2: 294-298

31. Schifferli JA, Steiger G, Paccaud J-P, Sjoholm AG, Hauptmann $G$ (1986) Difference in the biological properties of the two forms of the fourth component of human complement (C4). Clin Exp Immunol 63: 473-477

32. Rynes RI (1982) Inherited complement deficiency status and SLE. Clin Rheum Dis 8: $29-47$

Received: 7 October 1986

and in revised form: 6 April 1987

Dr. J.A.Charlesworth

Renal Unit

Prince Henry Hospital

Little Bay, N.S. W. 2036

Australia 